\title{
Microeconomic Impact of GST on Household Consumption Patterns in Pakistan
}

\author{
Zahid Iqbal, Muhammad Salahuddin Ayyubi, Abdul Farooq and Sumaira Lodhi ${ }^{1}$
}

\begin{abstract}
This study is aimed at examining the impact of GST (General Sales Tax) insinuation on household consumption and social welfare in Pakistan with a special focus on indirect tax reforms in the country. Deterministic simulation experiments with different rates of GST were carried out for tax policy implication in the country. The results suggested that the government can raise tax revenue by raising price of food as it came out to be a good nominee for taxable commodities. Health related expenditure by households was also inelastic in nature, therefore, the study proposed that taxes must be imposed on goods that have relatively inelastic demand as the marginal cost of tax rate and social welfare loss is minimum in case of inelastic goods. Results from simulation and inequality aversion showed that consumer price of food need to be decoupled which is not possible in case of Pakistan. However, social inequality will upsurge as food is a necessity and when tax is imposed on the necessities, poor sections of the society become more vulnerable. As regard the tax policy implication, GST in VAT (Value Added Tax) mode should be more adopted because of its less distortionary nature as it is imposed on both goods and services and helps in widening the tax base.
\end{abstract}

Keywords: Household Behavior, Consumption, Taxation, Simulation, Social Inequality.

\section{JEL Classification : C15, D1, D63, E2, H2,}

\section{Introduction}

Indirect taxation has gained growing attention in the developing world from market participants, policy makers, politicians and academics in the twenty first century. This has been widely studied (Pasha and Ghaus-Pasha (2013); Aasness et al. (2002); Steindel (2001); Tanzi and Zee (2001); Creedy (1999); Deaton and Grimard (1992). Pakistan is one such country where taxation holds immense importance in revenue generation and welfare benefits of the masses. Pasha (20210)

\footnotetext{
${ }^{1}$ The authors are Associate Professor \& Assistant Professor at Departments of Economics, Forman Christian College (A Chartered University), Assistant Professor at COMSATS University Islamabad, Lahore Campus and Lecturer at Departments of Economics, Forman Christian College (A Chartered University) Lahore, respectively.

Corresponding author's Email: zahidiqbal@fccollege.edu.pk
} 
argued the inability of existing tax structure of Pakistan to generate enough revenues that are required to provide the basic necessities to the people. Therefore, a good understanding of the behavioural and welfare impact of indirect taxation is important in case of Pakistan because a significant increase in tax collection is required to finance the additional social and infrastructural spending in the country. However, it is argued that existing tax reforms need amendments in their structure and the way taxes are imposed needs to be revised. (Pasha and Ghaus-Pasha, 2013).

According to Deaton and Grimard (1992), Pakistan is a country where most of the revenue is obtained through indirect taxation that may alter consumption patterns at household level. Tax system may create distortions in the market prices of commodities consumed. Variations in taxes benefit or hurt people but conditioned on how much they buy or sell goods considered, so that the effects on equity rest on demand and supply patterns, along with the extent to which the government is fretful to use taxes and subsidies as a tool of welfare policy (Deaton and Grimard , 1999). ${ }^{2}$ Creedy (1999) held that the tax policy maker is indifferent about the welfare considerations of configuring a tax rate only about the items for which own and cross price elasticities of demand are zero, otherwise (as is usually the case), he must attempt welfare maximization as the ultimate goal of tax policy. ${ }^{3}$

The objective of this study is to examine the impact of indirect taxation on consumer demand in Pakistan and to test statistically the generally held belief that an increase in prices (due to indirect taxes on aggregate commodity groups), drastically alters consumption patterns of households. The main objectives of this study are to estimate the expenditure/income and price (own price and cross price) including the compensated and uncompensated elasticities of food and non-food commodities with and without tax. The estimated price elasticities and income elasticities of demand will be used to see which goods should be taxed more than average tax rate and which goods must be taxed less than average tax rate. The study is organized into five sections. Section I presents the introduction, section II carrys the literature review, section III briefly examines QUAIDS (Quadratic Almost Ideal Demand System) model, section IV revolves around simulation procedure and tax analysis and section $\mathrm{V}$ concludes the whole study using results presented in Section IV of the study.

\footnotetext{
${ }^{2}$ Also see Refaqat (2003), Savard (2003), Robilliard and Robinson (2001), Lahiri, Nasim and Ghani (2000), Siddique and Iqbal (1999), and McCathy and Taylor (1980).

${ }^{3}$ Also see Vaqar, Abbas and Ahmed (2008) for CGE and micro simulation analysis for Pakistan.
} 


\section{Literature Review}

Taxation has a significant impact on the household spending decisions in developing as well as developed countries. Moreover, it can be observed from the literature review that economists propose a uniform tax structure to be a better policy option that could help in improved budget allocation and maximize household welfare across different income groups. Furthermore, it is evident that studying consumer demand patterns and the impact of change in tax rate will provide a direction of a tax reform for a developing country like Pakistan where micro data studies are only a few in numbers. Deaton and Grimard (1992) adopted the methodology of Deaton $(1988,1991)$ and analyzed tax reforms and the demand patterns of different commodities using Household Integrated Survey of (1984-85) Pakistan and explored that the available literature for Pakistan on price reforms and demand systems neglected many important assumptions of consumer preferences.

The literature and demand models were based upon restrictive and traditional assumptions. It also exposed that changing the price of goods with distorted price such as wheat, rice, oil and sugar will produce quantitatively important effects for other goods when taxed or subsidized. Deaton (1997) calculated indirect utilities before and after the tax reform was imposed and compensating variations were plotted which showed that each household experienced a welfare loss after a price rise. Creedy (1999) examined indirect tax reform in Australia and proposed an effective tax rate for commodity groups like food and health service, electricity, gas and fuel as inequality aversion was absent for these stated groups. Steindel (2001) studied whether tax cuts lead to a rise in consumer spending or not and suggested that the consumers alter their spending only when there is an expected or actual change in their cash income because spending behavior is conditional to cash in hand, therefore, change in tax changes consumer spending only if the take home pay is directly influenced by tax imposition because spending is more responsive to permanent changes rather than momentary change. Aasness et al. (2002) assessed the distributional efficiency of the change in twelve different direct as well as indirect taxes in Norwegian tax system $^{4}$ and showed that all the twelve tax reforms generated an increased welfare as measured by their average standard of living and welfare on one hand, and a more equal distribution of the standard of living on the other. Raychaudhuri et al. (2004) evaluated whether VAT was distorting poverty in India and identified three items (LPG, mil (liquid) and Biscuits) for which taxes were progressive and

\footnotetext{
${ }^{4}$ Ahmad and Stern (1984) and Decoster and Schokkaert (1989) also analyzed optimality of indirect tax reforms
} 
concluded that replacing sales tax with VAT was beneficial for the poor in India. ${ }^{5}$ Ahmad and Arshad (2007), on the other hand, scrutinized household data and proposed that uniform tax structure was a better policy option that could help in improved budget allocation and maximized household welfare different income levels. Abramovsky et al. (2012) investigated consumer demand in Mexico using QUAIDS and held that VAT rate structure was not optimal for Mexico given the existing pattern of substitutability and complementarity between consumption and work. Urzua (2012) scrutinized the marginal tax reform methodology earlier proposed by Ahmad and Stern (1984) who assessed the local impact of a tax reform by using first order approximations of the relevant variables. ${ }^{6}$

Application of QUAIDS model by using micro data has remained a common tool to analyze the consumption patterns in different parts of the world but there were only a few studies (Mudassir et al., 2012; Naz, 2018). Jones and Mazzi (1996) analyzed tobacco consumption in Italy using QUAIDS model while Mittal (2010) applied QUAIDS to the food sector in India. Molina and Gil (2005) studied consumer demand behavior in Peru using QUAIDS. With regard to the application of QUAIDS and other methods that aimed at studying consumer demand in Pakistan, the present study has estimated QUAIDS model to measure social welfare cost of tax on food and nonfood items separately.

QUAIDS incorporates the impact and measurement of taxation on household consumer demand patterns. Ahmad and Stern (1984) estimated a demand model that was duplicated in various other studies for demand analysis and measured the impact of taxation on demand patterns and social welfare. ${ }^{7}$ This study will also make use of the method adopted by Ahmad and Stern (1984). The study conducted by the authors evaluated the optimality of an indirect tax structure by comparing the marginal cost in terms of social welfare of increasing extra unit of revenue through a tax increase on each good. Else a Pareto improvement could be effortlessly instigated by dropping the excise tax on the good with the higher

\footnotetext{
${ }^{5}$ Sinha (2002), Sinha and Raychaudhuri (1998) and Raychaudhuri and Sinha (2004) also discussed the optimality of VAT and previous sales tax regime in India. Apart from these studies, Son (2003) conducted a study on VAT implication and poverty reduction in Thailand while Son and Kakwani (2004) did a research on Asian countries regarding growth elasticity of poverty. All these aforementioned studies focused on seeing the impact of VAT and its poverty improving power in different regions.

${ }^{6}$ Also see Ahmad, Ehtisham and Al-Faris (2010); Bird and Richard (2010); Boadway (2010); Ahmad, Ehtisham and Brosio (2009); Martinez-Vasquez, Jorge and Richter (2008); Ambrosiano, Flavia and Bordignon (2006); Bahl, Roy; Wallace and Cyan (2008); Breton and Albert (2002)

${ }^{7}$ Banks, Blundell, and Lewbel (1996), Creedy (1999) and Urzua (2012).
} 
marginal cost and by raising the tax on the good with relatively lower marginal cost.

\section{QUAIDS Model}

Since, the primary aim of the study was to see the impact of GST using elasticities computed by employing QUAIDS model of Banks, Blundell, and Lewbel (1997). The data set was obtained from various issues of HIES (Household Income and Expenditure Survey) which provided essential data on income of family, their savings, liabilities, expenditures on goods and services and consumption trends at all national, provincial and rural/urban levels. The analysis of the study was based upon 16341 households.

The following equation for $\mathrm{w}_{\mathrm{i}}$, the share of expenditure on good $\mathrm{i}$ in total expenditures holds, for each household;

$$
w i=\beta i+\sum_{j=1}^{n} \gamma i j \ln (p j)+\delta i \ln \left(\frac{x}{a(p)}\right)+\frac{\lambda i}{b(p)}\left(\ln \left(\frac{x}{a(p)}\right)\right)^{2}
$$

Where $i=1 \ldots n$ denotes a good. This equation has been estimated to compute elasticities using HIES data (2010-2011) and the calculated elasticity estimates are given in the first author's $\mathrm{PhD}$ thesis (Iqbal, 2015).

$$
\delta_{i} \approx \frac{\sum_{h} \delta^{h}\left[1+\frac{\delta t_{i}}{\delta q_{i}} \varepsilon_{i i}^{h}\right] q_{i} x_{i}^{h}}{\left[1+\frac{\delta t_{i}}{q_{i}} \varepsilon_{i i}\right] q_{i} X_{i}+\sum_{k} \tau_{k}\left[1+\frac{\delta t_{i}}{2 q_{i}}\left(\varepsilon_{k i}-1\right)\right] \varepsilon_{k i} q_{k} X_{k}}
$$

Equation 2 is more simplistic and realistic as it allows for non-marginal tax changes. For derivations and further details of the expressions given in Equation 2, Urzua (2012) can be referred. The current study entails both ways as adopted by Ahmad and Stern (1984) and Urzua (2012) to see tax effects on social welfare of the households.

The marginal social cost on good $\mathrm{i}$ was worked out by using the given equation;

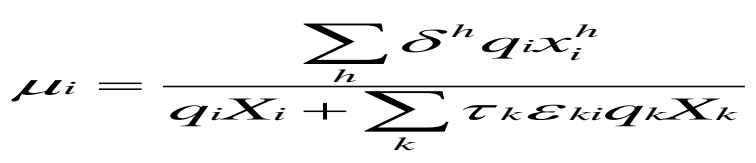

The detailed discussion of the expression 3 has been provided in Ahmad and Stern (1984, p 265). The computation of marginal cost across each good $i$ is 
required in order to apply Ahmad and Stern's (1984) methodology. Moreover, the data of final consumer prices, the welfare weights for all households, the consumption levels, and the aggregate responses of demand represented by the cross-price elasticities is required for the model estimation. The elasticities used in this study were computed in the first author's $\mathrm{PhD}$ thesis.

\section{Simulation Procedure and Tax Analysis}

Once the estimation of the behavioral equations is completed, different simulation experiments can then be conducted for better understanding of the completed demand system under consideration i.e. QUAIDS. Simulation experiments require numerical solution of the model as a whole system of equations while combining both the estimated equations as well as identities. When a model is simulated, the model as a whole moved in an integrated form, thus, providing predicted values of all the endogenous variables. On the basis of the results, obtained from the simulation, the model can then be used for the policy implications. ${ }^{8}$

This study conducted a number of experiments, keeping in view the dual functions in mind, including historical evaluation of model and baseline experiment. Based on the assumptions about the error terms in the model, there were two types of simulation i.e. deterministic and non-deterministic (stochastic) simulations. The focus of this study is deterministic simulation approach where error terms are generally set equal to their expected values, which are equal to zero, as each behavioural equation in the study contains an intercept term. On the other hand, stochastic stimulation involves a vector of error terms that are distributed as a multivariate normal distribution with mean zero and a constant variancecovariance matrix $\sum$. Deterministic simulations have an edge over nondeterministic simulations in their dual role of testing the reliability of the developed system of demand equations and analysis of macroeconomic policies. The deterministic model can be solved by using Guass-Siedel technique.

Abramovsky (2012) analyzed consumer demand in Mexico. The estimated consumer demand model was simulated to see the effects of reforms to taxes on consumer welfare and tax revenue accounting for changes in spending patterns. The current study also follows the steps of simulation experiment that was taken in the study of Abramovsky (2012). Changes in indirect taxes are modelled as changes in the prices of the food and non-food groups included in the demand system. VAT

\footnotetext{
${ }^{8}$ Also see Ahmed and Donoghue (2007) for microsimulation analysis using micro data and Annabi, Fatou, John and Decaluwe (2005).
} 
has not yet been implemented in Pakistan because of certain complexities associated with classification of goods into different tax rate schedules. Here, we analyzed the impact of a counterfactual VAT reform of varying rates applied to all goods and services. The study shall follow the general framework of this article in carrying out simulation experiments, if not the details.

Likewise, Dybczak (2010) computed compensated and uncompensated elasticities by estimated a demand system for Czech Republic. The estimated parameters of the demand system and estimates of elasticities were then used to scrutinize the effect of adjustments in regulated prices on consumer demand. QUAIDS model was used to simulate the impact of exogenous prices (because regulated prices are set by the regulatory authority and these are not adjusted by the market forces) on consumer demand of the eight commodity groups taken into account. In this study, we took all the needed steps of the simulation process. Firstly, the shares of regulated prices in the specific commodity bundles were quantified. Secondly, the quantification of various percentage changes in a specific regulated price was done to see how this change translated into the price of a specific commodity bundle. Thirdly, the impact on consumption shares, expenditure, and quantity purchased of specific commodity bundles before and after the change was quantified by applying the estimated elasticities.

The simulation procedure in the current study was carried in various sequential steps. Once the budgets share of commodity groups were estimated using SUR technique. Original price values were put in the estimated equations (i.e. prices without GST). After obtaining the estimated values, expected values were obtained, and then the simulation experiments were carried out. After conducting the simulation experiment, we used GST inclusive prices and performed $p_{1}{ }^{*}, p_{2}{ }^{*}, \ldots, p_{8}^{*}$ then simulation experiments where parameters of budget share equations remained the same while prices changed. The following budget share equations were estimated for the eight commodity groups considered in analysis;

$$
\begin{aligned}
& s_{1}=\beta_{1 o}+\beta_{11} p_{1}+\beta_{12} p_{2}+\beta_{13} p_{3}+\beta_{14} p_{4}+\beta_{15} p_{5}+\beta_{16} p_{6}+\beta_{17} p_{7}+\beta_{18} p_{8}+\gamma_{11} X+\gamma_{12} X^{2}+\mu_{1} \\
& s_{2}=\beta_{2 o}+\beta_{21} p_{1}+\beta_{22} p_{2}+\beta_{23} p_{3}+\beta_{24} p_{4}+\beta_{25} p_{5}+\beta_{26} p_{6}+\beta_{27} p_{7}+\beta_{28} p_{8}+\gamma_{21} X+\gamma_{22} X^{2}+\mu_{2}
\end{aligned}
$$

$$
s_{8}=\beta_{80}+\beta_{81} p_{1}+\beta_{82} p_{2}+\beta_{83} p_{3}+\beta_{84} p_{4}+\beta_{85} p_{5}+\beta_{86} p_{6}+\beta_{87} p_{7}+\beta_{88} p_{8}+\gamma_{81} X+\gamma_{82} X^{2}+\mu_{8}
$$

The equation 4 can be written in the matrix form as; 
$Y=X \beta+\varepsilon$

where;

$$
\varepsilon=\left[\begin{array}{c}
\mu_{1} \\
\mu_{2} \\
\mu_{3} \\
\mu_{4} \\
\cdot \\
\cdot \\
\mu_{8}
\end{array}\right]
$$

Assuming;

$\varepsilon \sim N(0,1)$

Then;

$E(Y / X)=X \hat{\beta}$

That is;

$E(Y / X)=\left[\begin{array}{cccccc}\hat{\beta}_{11} & \ldots & \hat{\beta}_{17} & \hat{\beta}_{18} & \gamma_{11} & \gamma_{12} \\ \hat{\beta}_{21} & \ldots & \hat{\beta}_{27} & \hat{\beta}_{28} & \gamma_{21} & \gamma_{22} \\ \hat{\beta}_{31} & \ldots & \hat{\beta}_{37} & \hat{\beta}_{38} & \gamma_{31} & \gamma_{32} \\ \hat{\beta}_{41} & \ldots & \hat{\beta}_{47} & \hat{\beta}_{48} & \gamma_{41} & \gamma_{42} \\ \vdots & & \vdots & \vdots & \vdots & \vdots \\ \hat{\beta}_{81} & \ldots & \hat{\beta}_{87} & \hat{\beta}_{88} & \gamma_{81} & \gamma_{82}\end{array}\right]=\left[\begin{array}{c}P_{1} \\ P_{2} \\ P_{3} \\ \vdots \\ P_{8} \\ X \\ X^{2}\end{array}\right]$

For;

$P_{1}=P_{1}^{*}, \quad P_{2}=P_{2}^{*}, \quad P_{3}=P_{3}^{*}, \cdots P_{8}=P_{8}^{*}$

This arrangement provided us the expected values of different shares of commodity groups for base line experiment. Base line experiment will be used to compare the results of the rest of the simulation experiments. 
Experiment 2:

We replaced the values of explanatory variables given below;

$P_{1}=P_{1}^{*} \quad$ while $\quad P_{i}=P_{i}^{*}+0.15 P_{i}^{*} \quad$ where $i=2,3, \ldots, 8$

The system was then solved to get the expected values of the eight shares of commodity groups.

Experiment 3:

$P_{1}=P_{1}^{*} \quad$ while $\quad P_{i}=P_{i}^{*}+0.17 P_{i}^{*} \quad$ where $i=2,3, \ldots, 8$

Experiment 4:

$P_{1}=P_{1}^{*} \quad$ while $\quad P_{i}=P_{i}^{*}+0.10 P_{i}^{*} \quad$ where $i=2,3, \ldots, 8$

Experiment 5:

$P_{1}=P_{1}^{*} \quad$ while $\quad P_{i}=P_{i}^{*}+0.03 P_{i}^{*} \quad$ where $i=2,3, \ldots, 8$

Similarly, the experiments were repeated for the other GST rates as well. After six attempts of simulation experiments using deterministic approach, we compared the results presented in Table $1 .^{9}$

Table 1 presents the social welfare cost of GST in Pakistan for various commodity groups ranging from food group to miscellaneous items. The results are represented at different levels of inequality aversion.

The results in first column of table 1 indicate the absence of inequality aversion i.e. $\mathrm{e}=0$ when there is no inequality aversion, goods that can be taxed are items in personal expenditure group as the social welfare cost is minimum when this group will be taxed in Pakistan. However, when the level of inequality aversion shifted from 0 to 1 i.e. when $e=1$, health and personal care was found to be a good candidate for GST imposition. Clothing came out to be a good candidate for taxation as the social welfare loss (0.011) resulting from indirect taxation was lowest in case of clothing group as compared to other commodity groups including food, housing, fuel and lighting, health and personal care, personal expenditure,

\footnotetext{
${ }^{9}$ Also see Ahmad, Ehtisham and Abdelrazak Al-Faris (2010), Bird and Richard (2010), Boadway (2010), Ahmad, Ehtisham and Giorgio Brosio (2009) for simulation procedures.
} 
education and miscellaneous. At $\mathrm{e}=1$, group that could be taxed after clothing group was observed to be food (0.033) following miscellaneous $(0.045)$, education and personal expenditure (0.064), fuel and lighting (0.074), housing (0.085) and lastly health and personal care (0.354).

Table 1: Social Welfare Costs of GST in Pakistan

\begin{tabular}{lllll}
\hline $\begin{array}{l}\text { Commodity } \\
\text { Group }\end{array}$ & \multicolumn{4}{l}{ Various levels of inequality aversion } \\
\hline & $\mathrm{e}=0$ & $\mathrm{e}=1$ & $\mathrm{e}=2$ & $\mathrm{e}=3$ \\
Food & 1.124 & $0.748^{10}$ & 0.033 & 0.013 \\
& 1.128 & 0.825 & 0.042 & 0.014 \\
Housing & 1.114 & 0.925 & 0.085 & 0.006 \\
& 1.129 & 0.885 & 0.081 & 0.006 \\
Clothing & 1.102 & 0.874 & 0.011 & 0.005 \\
& 1.112 & 0.860 & 0.017 & 0.008 \\
Fuel and & 1.121 & 0.745 & 0.074 & 0.061 \\
Lighting & 1.124 & 0.694 & 0.045 & 0.054 \\
Health and & 0.964 & 0.645 & 0.354 & 0.064 \\
Personal Care & 0.987 & 0.515 & 0.359 & 0.058 \\
Personal & 0.856 & 0.745 & 0.064 & 0.004 \\
Expenditure & 0.954 & 0.751 & 0.077 & 0.004 \\
Education & 1.012 & 0.845 & 0.064 & 0.002 \\
& 1.045 & 0.832 & 0.062 & 0.008 \\
Miscellaneous & 1.127 & 0.954 & 0.054 & 0.001 \\
& 1.065 & 0.924 & 0.051 & 0.002 \\
\hline
\end{tabular}

At $\mathrm{e}=2$, the most taxable commodity group was clothing $(0.011)$ followed by food, miscellaneous, personal expenditure, education, fuel and lighting, housing and health and personal care. When inequality aversion was equal to 3 , then the social welfare loss was minimum when GST was imposed on clothing.

On the other hand, when the level of inequality aversion was equal to 3 (i.e. when e=3), miscellaneous group was observed to be a taxable group in the presence of inequality aversion followed by education (0.002), personal expenditure (0.004) and clothing (0.005), housing (0.006), food (0.013) fuel and lighting (0.061) and health and personal care (0.064).

\footnotetext{
${ }^{10}$ The first value in each cell of the table 1 represents $\delta_{i}$ as represented in Equation 2 and the second value in each cell shows $\mu_{i}$ as represented by Equation 3 .
} 
There are different measures of inequality including positive and normative measures of inequality. Positive measures of inequality quantify the extent of inequality by employing statistical measures of dispersion in an objective manner while normative measures are based upon explicit formulation of a social welfare function that indicates the social welfare loss incurred due to unequal distribution of income or consumption. ${ }^{11}$ Creedy (1999) expounded the concepts of inequality aversion through 'leaky bucket' mental experiment where the allocation of one dollar to another person might involve some loss. The author also computed social welfare cost along with expenditure elasticities, using the data set of HIES 1988 for Australia, as it helped in determining the directions for tax reform. Similarly, the present study also utilized HIES data to see the social welfare cost of GST in Pakistan.

Idrees (2006) analyzed consumption and income inequalities in Pakistan using alternative approaches to measure inequalities. Haq (1989) provided a better understanding of consumption inequality in Pakistan in food and non-food items. The author used both income and expenditure data keeping in view the errors that may result using income data in Pakistan. Income data of Pakistan is considered to be more erroneous due to under reporting so in order to validate the results, the authors of this study utilized both the income and expenditure approach.

The figures in Table 2 represent change in average expenditure shares (in percentage) after change in GST. The overall results represent that people in Pakistan devote a larger percentage share on the consumption of food followed by housing, miscellaneous goods and fuel and lighting as compared to any other commodity group considered here. The baseline column represents the budget share for commodities without tax while remaining column represent the budget share of food, housing clothing, fuel and lighting, health and personal care, personal expenditure, education and miscellaneous items. The simulation results with $15 \%$ GST on all items indicate that when food was imposed with $15 \%$ GST, its percentage share in the budget increased by 3 percent, in case of housing the budget share devoted to housing decreased by 0.64 percent. On the other hand, the results indicated a decrease in budget share of health and personal care ( 0.01 percent), personal expenditure. When commodity groups of education and miscellaneous items was considered then it was observed that imposition of $15 \%$ GST on these groups increased their overall budget expenditure by 0.05 and 0.2 percent, respectively. However, the percentage expenditure share of fuel and lighting was unaffected with the imposition of $15 \%$ GST on all the items. The results in column

\footnotetext{
${ }^{11}$ For further details of measures of inequality, see Idrees (2006).
} 
2 and 5 of Table 2 are comparable and it shows that with 10\% GST on all items, average share of food expenditure is less than the average share of food expenditure when all items are imposed with 15\% GST. On the other hand, it can also be observed that column 4 and 7 are comparable in Table 2. In conclusion, personal expenditure group was nominated as the most important and taxable commodity among all other groups with $15 \%$ GST on all items.

Table 2: Changes in Average Expenditure (in percentage) Shares after Changes in GST

\begin{tabular}{|c|c|c|c|c|c|c|c|}
\hline \multirow{8}{*}{$\begin{array}{l}\text { Commodity } \\
\text { groups }\end{array}$} & \multicolumn{7}{|c|}{ Expected Share of good $\mathrm{i}$ in total expenditure } \\
\hline & Base & $15 \%$ & $15 \%$ & $0 \%$ & $10 \%$ & $3 \%$ & $0 \%$ \\
\hline & line & GST & GST & GST & GST & GST & GST \\
\hline & & on all & other & on food & on all & on food & on food \\
\hline & & items & than & & items & & and \\
\hline & & & food & $17 \%$ on & & $14 \%$ on & $13 \%$ on \\
\hline & & & & other & & other & other \\
\hline & & & & Items & & items & Items \\
\hline Food & 44.65 & 47.65 & 42.75 & 42.89 & 45.98 & 45.62 & 42.04 \\
\hline Housing & 11.32 & 11.96 & 12.04 & 12.34 & 12.64 & 12.79 & 12.98 \\
\hline Clothing & 4.57 & 4.63 & 4.67 & 4.89 & 4.64 & 4.79 & 4.75 \\
\hline Fuel and & 6.76 & 6.76 & 6.92 & 6.94 & 6.72 & 6.54 & 6.89 \\
\hline Lighting & & & & & & & \\
\hline Health and & 4.62 & 4.61 & 4.72 & 4.57 & 4.68 & 4.57 & 4.92 \\
\hline Personal Care & & & & & & & \\
\hline Personal & 2.18 & 2.14 & 2.69 & 2.54 & 2.98 & 2.79 & 2.98 \\
\hline Expenditure & & & & & & & \\
\hline Education & 4.10 & 4.15 & 4.69 & 4.71 & 4.89 & 4.79 & 4.97 \\
\hline Miscellaneous & 11.78 & 11.98 & 12.14 & 11.89 & 12.08 & 12.2 & 11.95 \\
\hline
\end{tabular}

When simulation experiment that aimed at imposing 15\% GST on all items other than the food group was conducted, the results revealed that the percentage share of expenditure on food decreased by 1.9 percent while remaining budget share expenditure on all items increased by 0.72 percent for housing, 0.1 percent for clothing and Health and Personal Care, 0.2 percent for Fuel and Lighting, 0.51 percent for personal expenditure, 0.59 percent for education and 0.36 percent in case of miscellaneous items. When imposing $15 \%$ GST on all items other than the food group was imposed, personal expenditure group again came out to be a good nominee for taxation. Therefore, if food is not imposed with GST so that poorer 
sections is not worse off, then, personal care and fuel and lighting remains there as good options for GST insinuation in Pakistan.

Likewise, when $0 \%$ GST was imposed on food group while $17 \%$ on all other commodity groups, it was observed that the percentage budget share expenditure on food decreased by 1.76 percent on food items and same was the case with Health and Personal Care where it decreased by 0.05 percent. When five commodity group including housing, clothing, fuel and lighting, personal expenditure, education and miscellaneous goods percentage budget share expenditure was considered, results stipulated that it increased by 1.02 percent for housing, 0.32 percent for clothing, 0.18 percent for Fuel and Lighting, 0.36 percent for personal expenditure, 0.61 percent for education and 0.11 percent in case of miscellaneous goods. A $17 \%$ GST on health and personal care had a negligible effect on its average budget share expenditure. However, personal expenditure group again came out to be a good nominee for $17 \%$ GST when accompanied by 0\% GST on food.

In addition to this, $10 \%$ of GST on exposed that the average percentage budget share expenditure on all commodity groups other than fuel and lighting increased. In case of food items, it increased by 1.33 percent following by 1.32 percent for housing, 0.07 percent in case of clothing, 0.06 percent for Health and Personal Care, 0.8 percent for Personal Expenditure, 0.79 percent in case of education and lastly 0.3 percent increase in average percentage budget share expenditure on miscellaneous items. Simulation experiment of this kind made personal expenditure group once again a taxable commodity group. Conversely, when $3 \%$ GST on food and $14 \%$ on other items were imposed, the simulated experiment indicated that the average budget share on all commodity groups increased except that of fuel and lighting and health and personal care expenditures. The expenditure share of food increased by 0.97 percent which was followed by 1.47 percent for housing, 0.22 percent for clothing, 0.61 percent for personal expenditure, 0.69 percent for education and 0.42 percent increase in the average budget share expenditure on miscellaneous items. Contrariwise, 0\% GST on food and $13 \%$ on other Items revealed an increase in budget share expenditures on all items except food where it showed a decline in 2.61 percent.

\section{Conclusions}

The objective of this study was to figure out the impact of indirect taxation on consumer demand in Pakistan and to test statistically the generally held belief that an increase in prices (due to indirect taxes on aggregate commodity groups), drastically alters consumption patterns of households. Based on the Data on Household Expenditure Surveys, results revealed that there was a significant 
difference between the consumption patterns of Pakistani households. Therefore, an alteration in tax reform would affect the consumption of aggregate commodity groups.

It was seen that aggregate commodity group related consumption and spending behaviors in the lives of Pakistani households were of critical importance for designing tax policy and reform in the country. QUAIDS model was estimated using SUR technique. The study exposed that decision that could be taken regarding which group should be taxed more or less varied at different levels of inequality aversion. If no inequality aversion $(\mathrm{e}=0)$ was the target, then, the policy makers must tax items of personal care as the social welfare loss was minimum if personal care items were imposed with GST. Similarly, other results could be used in view of set targets of tax authorities.

There is no doubt that VAT would bring enormous volume of revenue if applied in its true sense. VAT imposition, however, is not a suitable idea in case of Pakistan because the economy encompasses amalgam of certain informal and undocumented components. Food insecurity, low economic growth rates, high inflation, and unemployment rates have contributed to mounting poverty in the country. Therefore, instigating VAT in such circumstances would negatively affect the welfare of people who are living hand to mouth and those who are near the poverty line and even those who are counted in middle income group. Since, VAT would raise the prices of goods, lower middle class families will be pushed towards or below poverty line. Hence, VAT might be a good idea for developed economies but not for Pakistan. In view of aforementioned conclusions, it is recommended that VAT should not be imposed unless fitting measures intended at poor and vulnerable sections of the society have been ratified and strategies to ease the vulnerable have been uncovered. The current study suggests VAT imposition on tobacco and miscellaneous items because if food was taxed, households who are living closer to poverty line might be pushed below or towards it, thus, increasing social inequality in the society. Therefore, VAT insinuation may seem reasonable on economic grounds but it is not desirable on social grounds. 


\section{References}

Aasness, J., Benedictow, A., \& Hussein, M. F. (2002). Distributional efficiency of direct and indirect taxes. Economic Research Programme on Taxation Report, 69.

Abramovsky, L., Attanasio, O., \& Phillips, D. (2012). Demand responses to changes in consumer prices in Mexico: Lessons for policy and an application to the 2010 Mexican tax reforms. Institute for Fiscal Studies (IFS) mimeo, London, England.

Ahmad, E. (2010). Design of a VAT for the GCC Common Market. Ahmad and Al-Faris (Eds) Fiscal Reforms in the Middle East: VAT for the GCC, Edward Elgar.

Ahmad, E. and Al-Faris, A. (2010). Fiscal Reforms in the Middle East: VAT for the GCC. Edward Elgar.

Ahmad, E. and Brosio, G. (2009). Political Economy of Tax Assignments in Latin American Countries: Tax Autonomy versus Earmarked Revenues. National Tax Association, 100 ${ }^{\text {th }}$ Anniversary Proceedings, National Tax Journal, 191-205.

Ahmad, E., \& Arshad, M. (2007). Household budget analysis for Pakistan under varying the parameter approach. Pakistan Institute of Development Economics (PIDE) Working Paper Series, 2007:41.

Ahmad, E., and Ludlow, S. (1987) Aggregate and Regional Demand Response Patterns in Pakistan. The Pakistan Development Review, 26 (4): 645-657.

Ahmad, E., and Stern, N. (1991). Theory and Practice of Tax Reforms in Developing Countries. Cambridge University Press.

Ahmad, Ehtisham and Al-Faris, A. (2010). Fiscal Reforms in the Middle East: VAT for the GCC, Edward Elgar.

Ahmad, Ehtisham and Brosio, G. (2009). Political economy of tax assignments in Latin American countries: tax autonomy versus earmarked revenues, National Tax Association, 100th Anniversary Proceedings, National Tax Journal, pp. 191-205.

Ahmed, V. and Donoghue, C.O. (2007). Using CGE and Microsimulation Models for Income Distribution Analysis, Department of Economics, National University of Ireland Galway, Working Paper: 0089. 
Ambrosiano, Flavia and Bordignon, M. (2006). Normative and positive theories of revenue assignments, Ehtisham Ahmad and Giorgio Brosio, eds, Handbook of Fiscal Federalism, Edward Elgar.

Annabi, N., Cisse, F., Cockburn, J. and Decaluwe, B. (2005), Trade Liberalization, Growth and Poverty in Senegal: A Dynamic Microsimulation CGE Model Analysis. CPEII NO: 2005-07.

Bahl, Roy (1999). Implementation Rules for fiscal decentralization, International Studies Program, School of Policy Studies, Georgia State University, USA.

Bahl, Roy, Wallace, S., and Cyan, M. (2008). Pakistan: Provincial Government Taxation, International Studies Program, Working Paper 08-07

Banks, J., Blundell, R., \& Lewbel, A. (1997). Quadratic Engel curves and consumer demand. The Review of Economics and Statistics, 79(4), 527-539.

Bird and Richard (2010). Central and subnational VATs in Developing Countries, Ahmad and Al-Faris.

Bird, R. (2010). Central and Subnational VATs in Developing Countries. Ahmad and Al-Faris (Eds) Fiscal Reforms in the Middle East: VAT for the GCC, Cheltenham, UK: Edward Elgar.

Boadway, R. (2010). The Design of VAT for Multilevel Jurisdictions: Lessons from Canada. Ahmad and Al-Faris (Eds) Fiscal Reforms in the Middle East: VAT for the GCC, Cheltenham, UK: Edward Elgar.

Breton, A. (2002). An Introduction to Decentralization Failure, Ehtisham Ahmad and Vito Tanzi (eds.), Managing Fiscal Decentralization, London and New York: Routledge, 31-45.

Creedy, J. (1999). Indirect tax reform in Australia: The welfare effects on different demographic groups. Australian Economic Papers, Wiley Blackwell, 38(4), 367-92.

Deaton, A., \& Grimard, F. (1992). Demand analysis and tax reform in Pakistan. LSMS Working Papers, 0253-4517, Paper No. 85.

Decoster, A. and Schokkaert, E. (1990). Tax reform results with different demand systems. Journal of public economics, 41, 227-296. 
Decoster, A., \& Schokkaert, E. (1989). Equity and efficiency of a reform of Belgian indirect taxes. Recherches Économiques de Louvain/Louvain Economic Review, 59(2), 155-176.

Dybczak, K., Tóth, P., \& Voňka, D. (2010). Effects of price shocks to consumer demand: Estimating the QUAIDS demand system on Czech household budget survey data. Czech National Bank (CNB) Working Paper Series, 8/2010, 57-72.

Gemmell, N. and Morrissey O. (2005). Distribution and Poverty Impacts of Tax Structure Reform in Developing Countries: How Little We Know, Development Policy Review, Vol. 23(2):131-144.

Girma, S., \& Kedir, A. M. (2002). When does food stop being a luxury? Evidence from Quadratic Engel Curves with measurement error. Centre for Research in Economic Development and International Trade (CREDIT), University of Nottingham, 02/03.

Iqbal, Z. (2015) Estimating Household Demand System for Pakistan: An Implication of General Sales Tax, unpublished thesis presented and submitted in partial fulfillment of the requirement for the degree of Doctorate of Philosophy in Economics at Department of Economics Government College University, Faisalabad.

Jones, A., \& Mazzi, M. G. (1996). Tobacco consumption and taxation in Italy: an application of the QUAIDS model. Applied Economics, 28(5), 595-603.

Keen, M. and Lockwood, B. (2007). The Value Added Tax: Its Causes and Consequences, Warwick Economic Research Papers, 07/142.

Martinez-Vasquez, Jorge and Richter, K. (2008). Pakistan: Tax Policy Reporttapping tax bases for development. The World Bank.

McCathy , D., and Taylor. (1980). Macro Food Policy Planning: A General Equilibrium Model For Pakistan, The Review Of Economics And Statistics, 62:1 107-121.

Mittal, S. (2010). Application of the QUAIDS model to the food sector in India. Journal of Quantitative Economics, 8(1), 42-54.

Molina, J. A., \& Gil, A. I. (2005). The demand behaviour of consumers in Peru: a demographic analysis using the QUAIDS. The Journal of Developing Areas, 191-206. 
Naz, L., Ahmad, M., \& Arif, G. M. (2018). Estimating Food Demand System and Rural Household Welfare: A Case study from Pakistan. Business \& Economic Review, 10(4), 55-82.

Newhouse, D., and Zakharova, D. (2007). Distributional Implications of the VAT Reform in the Philippines, IMF Working paper, 07/153.

Pasha, A. G. (2010). Can Pakistan get out of the low tax-to-GDP trap? The Lahore Journal of Economics, 15(Special Edition), 171-185.

Pasha, A. G. (2012). Making devolution work in Pakistan. The Lahore Journal of Economics, 17 (Special Edition), 339-357.

Pasha, H. A., \& Pasha, A. G. (2013). The future path of tax reforms in Pakistan. Retrieved June $19^{\text {th }}$, 2014, from http://lahoreschoolofeconomics.blogspot.com/2013/12/the-future-path-oftax-reforms-in.html.

Poddar, S., and Kalita, J. (2010). Treatment of Financial Services under a GCC VAT. In Ahmad and Al-Faris (Eds) Fiscal Reforms in the Middle East: VAT for the GCC, Cheltenham, UK: Ahmad and Al-Faris, Edward Elgar.

Prieto Rodriguez, J., Jordan, D.R., and Sanz, J.F. (2005). Is a tax cut on cultural goods consumption actually desirable? A micro-simulation analysis applied to Spain, Fiscal Studies, 26(4): 549-575.

Raychaudhuri, A., \& Sinha, S. K. (2004). Fiscal reforms initiatives in India: An indirect tax perspective, Purusottam Bhattacharya, Tridib Chakraborti and Shibashis Chatterjee (Eds.), Anatomy of Fear, Essays on India's Internal Security. New Delhi: Lancer's Books.

Refaqat, S. (2003). Social Inicdence Of The Gweneral Sales Tax In Pakistan, IMF working paper $03 / 216$.

Rider, M., and Ahmed, R.A. (2008). Pakistan's Tax Gap: Estimates by Tax Calculation and Methodology. The World Bank and Georgia State University.

Robilliard, A.S., and Robinson, S. (2001). Reconciling Household Surveys And National Accounts Data Using A Cross Entropy Estimation Method. TMD Discussion Paper no. 50, IFPRI.

Salti, N. and Chaaban, J. (2010). The Poverty and Equity Implications of a Rise in the Value added Tax: A Microeconomic Simulation for Lebanon, Journal of Economic Literature classification, 1:30. 
Savard , L. (2003). Poverty And Income Distribution In A CGE-Household MicroSimulation Model: Top-Down/Bottom Up Approach, Cnetre inteuniversitaire sur le risque, les politiques economiques et l'emploi, Cahier de recherche/Working Paper 03-43.

Siddique and Iqbal. (1999). Tariff Reduction And Functional Income Distribution In Pakistan; A CGE Model. Paper presented at the workshop on micro impact of macroeconomic adjustment policies, November 1999, Islamabad, Pakistan.

Sinha, S. (2002). Models of optimal commodity taxation with special reference to India. Unpublished thesis, accepted for the award of doctorate degree by Jadavpur University.

Sinha, S., \& Raychaudhuri, A. (1998). Some extensions of optimal commodity taxation: With special references to India. Journal of Economic Development, 23(2), 1-23.

Son, H., \& Kakwani, N. (2004). Economic growth and poverty reduction: Initial conditions matter. International Poverty Center, UNDP, Working Paper No. 2.

Tanzi, V. In Newbery, D., and Stern, N. (1987). Theory of Taxation for Developing Countries. Oxford University Press for the World Bank.

Urzúa, C. M. (2001). Welfare Consequences of a Recent Tax Reform in Mexico, Estudios.

Waerzeggers, C. (2010). The European VAT and the Common Market Framework. Ahmad and Al-Faris (Eds) Fiscal Reforms in the Middle East: VAT for the GCC, Cheltenham, UK: Edward Elgar. 